\title{
Search for donors of powdery mildew resistance genes among seedless and table grape varieties
}

\author{
Marina Makarkina, Elena Ilnitskaya*, and Tatiana Kozina \\ Federal State Budget Scientific Institution «North Caucasian Federal Scientific Center of \\ Horticulture, Viticulture, Wine-making», 350901 Krasnodar, Russia
}

\begin{abstract}
Powdery mildew (Erysiphe necator) is one of the most common and economically significant diseases of grapes. Currently, the main method of controlling the disease is pesticide treatment. Breeding of resistant varieties is necessary to reduce chemical treatments. Currently, a number of grape resistance genes to powdery mildew and DNA markers for identification the allelic status of these genes are known. In a study to determine the presence of resistance loci Ren 3 and Ren 9,25 genotypes of table grape varieties were analyzed, including 18 seedless varieties. DNA markers GF15-42, ScORGF15-02 were used to identify Ren3 gene, and CenGen6 - to identify Ren 9 gene. DNA of cultivars Regent and Seyve Villard 12-375, which have resistance alleles, were used as positive controls. As a result of DNA marker analysis, it was determined that genotypes of table varieties Viking, Kodryanka, Moldova, Nadezhda AZOS, Original and seedless varieties Pamyati Smirnova, Kishmish Zaporozhskiy and Kishmish 342 carry loci of resistance to powdery mildew Ren3 and Ren9.
\end{abstract}

\section{Introduction}

Table grapes are beneficial for the people, as they are rich in vitamins of groups A, C, D, E, $\mathrm{P}, \mathrm{K}, \mathrm{PP}$ and B, contain minerals, organic acids, etc. Grapes are one of the products that can be eaten both fresh and dried (raisins) [1]. Most often, the population chooses seedless grapes from table varieties for fresh consumption. Seedless grape varieties also play an influential role in the industry, as almost all dried products are made from them [2].

Fungal diseases pose a great threat to industrial viticulture, as they can lead to the loss of most of the harvest. One of these diseases is powdery mildew of vines. The causative agent of this disease is Erysiphe necator Schwein. - biotrophic ascomycete, which colonizes the epidermal cells of photosynthetic tissues and spreads through subsequent asexual cycles [3]. Infected leaves exhibit reduced photosynthesis and often prematurely age and fall off. Early infection of berries causes their cracking, and the overall impact on the harvest includes a decrease in yield, an increase in acidity and a decrease in the content of anthocyanin and sugar in mature berries. Even a low level of powdery mildew

\footnotetext{
*Corresponding author: ilnitskaya79@mail.ru
} 
contamination of berries can lead to spoilage of table grapes and a subsequent deterioration in varietal characteristics. [4].

Fungicidal treatments are currently used to control Erysiphe necator. However, for table varieties, this is not always safe, since there is a risk of accumulation of reagent residues in berries that are used for food by people. Therefore, an important task is to create genetically resistant to powdery mildew table grape varieties, which reduces the pesticide load on vineyards. The best quality characteristics of the harvest are possessed by European grapevines ( $V$. vinifera L.), among this species there are genotypes with tolerance to powdery mildew, but most varieties are susceptible to this disease. Resistance to Erysiphe necator is observed in North American ( $V$. riparia, $V$. aestivalis, $V$. rupestris, $V$. berlandieri, etc.), as well as in Asian (V. romanetii, $V$. piazezkii, etc.) grape varieties $[5,6]$. According to published data, currently more than 10 resistance loci have been identified, which are responsible for resistance to powdery mildew, they have a common symbolism of Run and Ren [7-12]. It was also possible to map the locus of resistance to Erysiphe necator in $V$. vinifera gene pool, namely in the genotypes of varieties Kishmish vatkana (Ren1) and Chardonnay (Sen1) [13, 14].

Ren 3 resistance locus was first described by Fischer et al. (2004) in a cross-population of "Regent" × "Lemberger" and additionally characterized by Welter et al. (2007) [15, 16]. Later, during the mapping of Ren3 locus in the same hybrid population, Zendler and his colleagues (2017) discovered Ren 9 resistance locus [11]. The Ren3 and Ren 9 loci were identified on chromosome 15, and DNA markers suitable for detecting the allelic status of these genes were identified $[11,16]$.

The purpose of this study is to search for donors of the genes of resistance to powdery mildew Ren 3 and Ren 9 among table and seedless grape varieties using recognized DNA markers.

\section{Materials and Methods}

The study included table and seedless grape varieties growing in the Anapa ampelographic collection, as well as in private farms.

In this work, we used markers GF15-42, ScORGF15-02 to identify Ren3 gene, and CenGen6 to identify Ren 9 gene. The Regent and Seyve Villard 12-375 varieties were used as positive controls - these genotypes carry alleles of resistance to powdery mildew.

DNA was isolated from the young leaves of the apical part of the shoots of the studied varieties using the CTAB method [17]. PCR was performed using reagents manufactured by $\mathrm{OOO}$ «SibEnzim-M» (Russia, Moscow). The volume of the reaction mixture was $20 \mu \mathrm{l}$, it contained $50 \mathrm{ng}$ of genomic DNA, 1.5 units of Tag polymerase, 1x buffer for Tag polymerase with ammonium sulfate and magnesium, $2 \mathrm{mM} \mathrm{MgCl} 2,0.2 \mathrm{mM}$ each dNTP (deoxynucleotide triphosphates). The conditions of the polymerase chain reaction with the marker CenGen6 have been tested in previous studies [18]. For the markers GF15-42 and SCORGF15-02, the annealing temperature of the primers was selected, equal to $60{ }^{\circ} \mathrm{C}$. The optimal protocol was chosen as follows: initial denaturation at $+95^{\circ} \mathrm{C}-5$ minutes; then 34 cycles of synthesis: denaturation -10 seconds at $+95^{\circ} \mathrm{C}$, annealing of primers -30 seconds at $+60{ }^{\circ} \mathrm{C}$, elongation -30 seconds at $+72{ }^{\circ} \mathrm{C}$; final elongation -3 minutes at $+72^{\circ} \mathrm{C}$.

The automatic genetic analyzer ABI Prism 3130 was used in the work, on it the fragments obtained by PCR were separated. The size of the amplified fragments was estimated using special software (GeneMapper and PeakScanner). The data obtained were corrected in accordance with the control varieties (Regent and Seyve Villard 12-375), which have a known allelic composition. 


\section{Results and Discussion}

There were analyzed 25 genotypes, including 18 seedless varieties. According to the literature data, the presence of Ren 3 allele of resistance to powdery mildew in grape genotypes correlates with fragments of 199 and 242 base pairs (bp) detected by markers GF15-42 and ScORGF15-02, respectively, determined by PCR analysis. The presence of Ren 9 resistance allele is determined by the detection of the PCR fragment $287 \mathrm{bp}$ when analyzing using the CenGen6 marker. Both resistance loci Ren 3 and Ren 9 were found in the genotypes of varieties Pamyati Smirnova, Viking, Kishmish Zaporozhskiy, Kishmish 342, Kodryanka, Moldova, Nadezhda AZOS, Original (table 1).

Table 1. Identified alleles for the studied loci, bp.

\begin{tabular}{|c|c|c|c|c|}
\hline \multirow{2}{*}{ Variety } & \multirow{2}{*}{ Pedigree } & \multicolumn{2}{|c|}{ Ren3 } & \multirow{2}{*}{$\begin{array}{c}\text { Ren } 9 \\
\text { CenGen6 }\end{array}$} \\
\hline & & GF15-42 & ScORGF15-02 & \\
\hline Regent (control) & $\begin{array}{c}\text { Diana x Chambourcin (Seyve Villard } \\
\mathbf{1 2 - 4 1 7} \text { x Seibel 7053) }\end{array}$ & 199 & 242 & $277: 287$ \\
\hline \begin{tabular}{|l|} 
Seyve Villard 12- \\
375 (control)
\end{tabular} & Seibel' 6468 x Seibel' 6905 & 199 & 242 & $276: 287$ \\
\hline $\begin{array}{l}\text { Pamyati } \\
\text { Smirnova* }\end{array}$ & $\begin{array}{l}\text { Seyve Villard 12-375 } \mathrm{x} \text { Kishmish } \\
\text { tairovskiy rozovyi }\end{array}$ & 199 & 242 & $277: 287$ \\
\hline Viking & $\begin{array}{c}\begin{array}{c}\text { ZOS-1 x Kodryanka (Moldova (Guzal } \\
\text { kara x Seyve Villard 12-375) x } \\
\text { Marshal'skiy) }\end{array} \\
\end{array}$ & 199 & 242 & 287 \\
\hline \begin{tabular}{|l|} 
Kishmish \\
Zaporozhskiy* $^{*}$
\end{tabular} & $\begin{array}{c}\text { Viktoriya x Rusbol (Seyve Villard 12- } \\
\mathbf{3 7 5} \text { x Sverhranniy bessemyannyi) }\end{array}$ & 179:199 & 242 & $277: 287$ \\
\hline Kishmish $342^{*}$ & Seyve Villard 12-375 x Perlette & 199 & $240: 242$ & $275: 287$ \\
\hline Kodryanka & $\begin{array}{c}\text { Moldova (Guzal kara x Seyve Villard } \\
\text { 12-375) x Marshal'skiy }\end{array}$ & 199 & 242 & $277: 287$ \\
\hline Moldova & Guzal kara x Seyve Villard 12-375 & 199 & 242 & $276: 287$ \\
\hline Nadezhda AZOS & $\begin{array}{c}\text { Moldova (Guzal kara x Seyve Villard } \\
\text { 12-375) x Cardinal }\end{array}$ & 199 & 242 & $277: 287$ \\
\hline Original & $\begin{array}{c}\text { Damasskaya roza x Dattier de St. } \\
\text { Vallier (Panse de Provence x Seyve } \\
\text { Villard 12-375) } \\
\end{array}$ & $185: 199$ & 242 & $277: 287$ \\
\hline Attika* $^{*}$ & $\begin{array}{c}\text { Alphonse Lavallee x Kishmish } \\
\text { chernyi }\end{array}$ & 179:195 & 240 & 276 \\
\hline $\begin{array}{l}\text { Bessemyannyi } \\
\text { Magaracha }^{*}\end{array}$ & \begin{tabular}{|c|} 
(Katta-Kurgan x Kirovobadskiy \\
stolovyi) x Sverhranniy bessemyannyi
\end{tabular} & $187: 224$ & 240 & 277 \\
\hline Vanessa seedless ${ }^{*}$ & Seneca $x$ New York 45910 & 193:199 & 239 & 277 \\
\hline Vostorg & $\begin{array}{c}\text { (Zarya severa x Dolores) x Russkiy } \\
\text { ranniy }\end{array}$ & 196 & 241 & 277 \\
\hline \begin{tabular}{|l|}
$\begin{array}{l}\text { Kishmish belyi } \\
\text { oval'nyi* }\end{array}$ \\
\end{tabular} & Ancient Central Asian variety & 185 & 240 & $275: 277$ \\
\hline Kishmish VIRa $^{*}$ & Babara x Kishmish chernyi & 187 & 240 & 277 \\
\hline $\begin{array}{l}\text { Kishmish } \\
\text { Moldavskiy* }\end{array}$ & Pobeda $x$ Kishmish rozovyi & 183 & 240 & $275: 277$ \\
\hline Kishmish rozovyi $^{*}$ & Ancient Armenian grape variety & 185 & 240 & $275: 277$ \\
\hline \begin{tabular}{|l|} 
Kishmish rozovyi \\
AZOS*
\end{tabular} & Kriulyanskiy x Yangi Er & $185: 191$ & 240 & $272: 277$ \\
\hline $\begin{array}{l}\text { Kishmish } \\
\text { Sogdiana }^{*} \\
\end{array}$ & Pobeda x Kishmish chernyi & 199 & 240 & $272: 285$ \\
\hline
\end{tabular}




\begin{tabular}{|l|c|c|c|c|}
$\begin{array}{l}\text { Kishmish chernyi } \\
\text { AZOS* }^{*}\end{array}$ & Kriulyanskiy x Yangi Er & $183: 193$ & 240 & $272: 277$ \\
\hline Mars $^{*}$ & Campbell early x Arkanzas 1339 & $187: 199$ & 239 & $275: 277$ \\
\hline Muskat letniy & $\begin{array}{c}\text { Seyve Villard 20-366 x Koenigin der } \\
\text { weingaerten }\end{array}$ & 196 & 240 & 277 \\
\hline Perlette* & Koroleva vinogradnikov x Sultanina & $193: 219$ & 240 & $275: 277$ \\
\hline Remaily Seedless $^{*}$ & Lady Patricia x NY 33979 & 179 & 240 & 277 \\
\hline Romulus $^{*}$ & Ontario x Kishmish belyi & 185 & 240 & 277 \\
\hline Ruby Seedless & Emperor x Sultanina muskatnaya & 179 & 240 & $275: 281$ \\
\hline
\end{tabular}

Note: target alleles and genotypes-donors of these alleles are highlighted in bold;

* - seedless grape varieties

Analyzing the pedigree of varieties in which resistance alleles were found, it can be concluded that in all these genotypes, the original donor of Ren 3 and Ren9 is Seyve Villard 12-375. In varieties Pamyati Smirnova, Moldova, Kishmish 342 genes are inherited directly from Seyve Villard 12-375. The varieties Viking, Kishmish Zaporozhskiy, Kodryanka, Nadezhda AZOS, Original inherited the resistance loci through the descendants of Seyve Villard 12-375 (table 1).

These varieties can be included in further breeding work on the creation of table grape varieties as donors of Ren 3 and Ren 9 genes, since, in addition to presence of these loci of resistance to powdery mildew, varieties have a complex of other economically valuable traits, bunches and berries have an attractive appearance. The genotypes of Pamyati Smirnova, Kishmish Zaporozhskiy and Kishmish 342 can be used in breeding of seedless grape varieties.

\section{Conclusion}

It was determined by DNA marker analysis that genotypes of table varieties Viking, Kodryanka, Moldova, Nadezhda AZOS, Original and seedless varieties Pamyati Smirnova, Kishmish Zaporozhskiy and Kishmish 342 carry loci of resistance to powdery mildew Ren 3 and Ren9.

\section{Acknowledgments}

The study was carried out within the framework of the state assignment and research project of the Russian Foundation for Basic Research and the Administration of the Krasnodar Region № 19-416230051 p_a

\section{References}

1. L. G. Naumova, Vinodelie i vinogradarstvo, 1, 36 - 38 (2004)

2. M. Akkurt, H. Tahmaz, S. Veziroğlu, South African Journal of Enology and Viticulture, 40 (2), 1-1 http://dx.doi.org/10.21548/42-2-3342.

3. W. Qiu, A. Feechan, I. Dry, Horticulture Research, 2, 1-9 (2015) https://doi.org/10.1038/hortres.2015.20

4. A. Calonnec, P. Cartolaro, C. Poupot, D. Dubourdieu, P. Darriet, Plant Pathol. 53 (4), 434-445 (2004) http://dx.doi.org/10.1111/j.0032-0862.2004.01016.x

5. L. Cadle-Davidson, D. Chicoine, N. Consolie, Plant disease, 95(2), 202-211 (2011) https://doi.org/10.1094/PDIS-02-10-0092 
6. Y. Wan, H. Schwaninger, P. He, Y. Wang, Vitis, 46(3), 132-136 (2007) https://doi.org/10.5073/vitis.2007.46.132-136

7. J. Pauquet, A. Bouquet, P. This, A. F. Adam-Blondon, Theoretical and applied genetics, 103, 1201-1210 (2001) https://doi.org/10.1007/s001220100664

8. M.A. Dalbó, G.N. Ye, N.F. Weeden, W.F. Wilcox, B.I. Reisch, J. Am. Soc. Horticult. Sci., 126(1), 83-89 (2001) https://doi.org/10.21273/JASHS.126.1.83

9. D. Pap, S. Riaz, I. B. Dry, A. Jermakow, A.C. Tenscher, D. Cantu, R. Oláh, M.A. Walker, BMC Plant Biology, 16(1), 1-19 (2016) DOI: 10.1186/s12870-016-0855-8

10. E. Zyprian, I. Ochßner, F. Schwander, S. Šimon, L. Hausmann, M. Bonow-Rex, P. Moreno-Sanz, M.S. Grando, S. Wiedemann-Merdinoglu, D. Merdinoglu, R. Eibach, R. Töpfer, Mol Genet Genomics, 291(4), 1573-94 (2016) https://doi.org/10.1007/s00438-016-1200-5

11. D. Zendler, P. Schneide, R. Töpfe, E. Zyprian, Euphytica, 213(68), 1029 (2017) https://doi.org/10.1007/s10681-017-1857-9

12. S.L. The, J. Fresnedo-Ramírez, M.D. Clark, D.M. Gadoury, Q. Sun, L. CadleDavidson, J.J. Luby, Molecular Breeding, 37(1), 1-16 (2017) https://doi.org/10.1007/s11032-016-0586-4

13. S. Hoffmann, G. Di Gaspero, L. Kovács, S. Howard, E. Kiss, Z. Galbács, R. Testolin, P. Kozma, Theoretical and applied genetics, 116(3), 427-438 (2008) https://doi.org/10.1007/s00122-007-0680-4

14. P. Barba, L. Cadle-Davidson, J. Harriman, J. C. Glaubitz, S. Brooks, K. Hyma, B. Reisch, Theoretical and applied genetics, 127(1), 73-84 (2014) https://doi.org/10.1007/s00122-013-2202-x

15. B.M. Fischer, I. Salakhutdinov, M. Akkurt, R. Eibach, K. Edwards, R. Töpfer, E.M. Zyprian, Theor Appl Genet, 108(3), 501-515 (2004) doi:10.1007/s00122-003-1445-3

16. L.J. Welter, N. Göktürk-Baydar, M. Akkurt, E. Maul, R. Eibach, R. Töpfer, E.M. Zyprian, Molecular Breeding, 20(4), 359-374 (2007) https://doi.org/10.1007/s11032-007-9097-7

17. S.O. Rogers, A.J. Bendich, Plant Mol. Biol., 19(1), 69-76 (1985) https://doi.org/10.1007/BF00020088

18. M.V. Makarkina, T.D. Kozina, E.A.Kozhevnikov, Nauchnye trudy SKFNCSVV, 33, 101-105 (2021) DOI: 10.30679/2587-9847-2021-33-101-105 